\title{
The material scope of competence of the European Public Prosecutor's Office: Lex uncerta and unpraevia?
}

\author{
John A.E. Vervaele
}

Published online: 27 February 2014

(C) ERA 2014

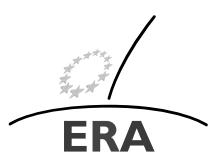

EUROPÄISCHE RECHTSAKADEMIE ACADEMY OF EUROPEAN LAW ACADEMIE DE DROIT EUROPEEN ACCADEMIA DI DIRITTO EUROPEO TRIER - TREVES - TREVIRI

\begin{abstract}
Article 86 TFEU provides a clear legal basis to establish the European Public Prosecutor's Office (EPPO) and to regulate its investigative and prosecutorial powers. Article 86 TFEU also refers to a limited substantive mandate, the protection of the financial interest of the Union, or to an extended mandate (based on an unanimous decision in the Council) including all serious crimes having a cross-border dimension. However, the Article remains silent on the precise scope of this material scope of competence. The 2013 Commission's EPPO proposal does not contain specific elements of the offences or penalties and refers to the proposal for a directive on the criminal law protection of the financial interest of the EU. The result will be that the material competence of the EPPO will at the end depend upon the patchwork of implementation provisions in every single Member State. In this article is assessed if this solution can comply with the substantive legality principle in criminal matters, being a human right under the ECHR and the Charter. The author makes a plea for an alternative solution and to regulate the material competence in the EPPO regulation itself.
\end{abstract}

This article is based on a presentation made at the Conference on The European Public Prosecutor's Office: "A Constructive Approach towards the Legal Framework", organised by the Lithuanian Ministry of Justice in cooperation with ERA and the European Commission on 16-17 September 2013 in Vilnius.

J.A.E. Vervaele, Professor in Economic and European Criminal Law and Co-Director $(\varangle)$ Utrecht Centre for Regulation and Enforcement in Europe (RENFORCE), Utrecht Law School, Utrecht, The Netherlands e-mail: J.A.E.Vervaele@uu.nl

J.A.E. Vervaele, Professor in European Criminal Law

College of Europe, Bruges, Belgium 
Keywords European Public Prosecutor's Office · Material scope of competence · Substantive legality principle $\cdot$ Protection of EU financial interests $\cdot$ European Convention of human rights · Charter of Fundamental Rights

\section{Introduction}

In any rule of law-based criminal justice system, it is of key importance that state powers to investigate, prosecute and punish (ius puniendi) are not only granted by law, but also subject to command and control by law. This control-restraint is the very essence of the rule of law and the "Rechtstaat", as the nation state has to guarantee both the liberty and the security of citizens. This has not only consequences for the way in which substantive criminal law is enacted, following the maxim of Beccaria, "nullum crimen, nulla poena sine lege", ${ }^{1}$ but also for the bridge between substantive criminal law and empowering the use of investigative and prosecutorial powers by judicial authorities, such as prosecutors. A suspect has to know for which offences he can be held criminal liable and which penalties can be applied (substantive legality). These offences and penalties must be laid down in clear, specific and definite terms (lex certa) and be foreseeable before the commission of the acts (lex praevia).

Moreover, the suspect has to know for which offences and under which legal requirement judicial authorities can use their investigative and prosecutorial powers (procedural legality). Coercive measures, such as search or telecommunication surveillance, can not be used without procedural thresholds and references to terms of substantive law (offences and penalties), as these infringe the right of privacy of persons. The material scope of competence of a prosecutor is thus not a left-over issue. It is an essential part of the design of the criminal justice system, as it triggers the procedural competence of the judicial authorities and the related procedural guarantees for the persons involved in criminal proceedings.

These key requirements, derived from the rule of law, were recognised as human rights and are laid down in Article 7 of the European Convention on Human Rights (ECHR) (substantive legality) and in Article 8 of the ECHR (procedural legality) and in their counterpart under EU law, in Article 49 of the Charter of Fundamental Rights of the European Union (substantive legality) and in Article 52(1) of the Charter (procedural legality).

This reasoning is mandatory not only for the use of ius puniendi at the level of the Member States, but also when investigative or prosecutorial functions are vested within a European Public Prosecutor's Office (EPPO). Even if the outcome of the debate on the proposal for an EPPO were that the model mainly or exclusively functioned through the EPPO Deputy in every single national jurisdiction-and thus by applying national law, the suspect would still have the right to lex certa and lex praevia when it comes to the substantive competence of the EPPO, even were this composed by the composite of several national jurisdictions in the Area of Freedom, Security and Justice (AFSJ).

${ }^{1} \mathrm{C}$. Beccaria, Dei delitti e delle pene, 1764, https://archive.org/details/deidelittiedelle00becc or Beccaria [3]; Krey [6]. 
In this article we will verify if the material scope of competence of the EPPO, as elaborated in the EPPO proposal, complies with the substantive legality principle under the Lisbon Treaty. Our analysis will include the proposed directive on the criminal law protection of the financial interests of the EU. We will conclude with a brief assessment of the compliance with the substantive legality principle of the EPPO proposal.

\section{The Treaty frame}

Article 86 TFEU provides a clear legal basis to establish the European Public Prosecutor's Office and also to elaborate the regulatory specificities when it comes to the investigation, prosecution and adjudication of crimes affecting the financial interest (PIF-crimes) of the European Union. However, Article 86 TFEU is silent on the precise scope of the competence ratione materiae of the EPPO, as it contains a limited reference to a basic mandate to combat crime affecting the financial interest of the EU or, after a unanimous decision in the Council, to an extended mandate to combat serious crimes having a cross-border dimension. This divide is the result from the negotiations in Working Group X of the European Convention preparing the draft Constitutional Treaty, where Member States did not agree as to the necessity and added value of an EPPO. ${ }^{2}$ Whereas some Member States wanted an EPPO to investigate and prosecute offences against the financial interests of the Union, others had a preference for an EPPO with a scope of action in line with the competences of Europol and Eurojust and also in line with the reach of the so-called euro-offences, which have been harmonised since the Treaty of Maastricht by conventions and framework decisions $^{3}$ and are the subject of further harmonisation under Article 83(1) TFEU. This divide resulted in the phrasing of the legal basis for the EPPO in Article III-274 of the draft Constitutional Treaty, which was to a very large extent copied and pasted to into Article 86 TFEU:

Article 86:

"In order to combat crimes affecting the financial interests of the Union, the Council, by means of regulations adopted in accordance with a special leg-

\footnotetext{
${ }^{2}$ See the Final report of Working Group X "Freedom, Security and Justice", CONV 426/02, http://european-convention.eu.int/pdf/reg/en/02/cv00/cv00426.en02.pdf, page 20: "The Group agrees on the objective of a more efficient prosecution of offences against the Union's financial interests. A significant number of members believe that current instruments are inadequate. The Group considered some proposals made in favour of the creation of a European Public Prosecutor responsible for detecting, prosecuting and bringing to judgement in the national courts the perpetrators of crimes prejudicial to the Union's financial interests. They have proposed that the Treaty should provide a legal basis to that effect. Others have considered that a convincing case was not made for the creation of such a body and that there were strong objections on both practical and accountability grounds. To some other Members, the need exists for a proper European Public Prosecutor's Office with a scope of action going beyond the protection of the financial interests of the Union. They believe that the current Eurojust could evolve towards that Office."

${ }^{3}$ In particular the French Conseil d'état demanded that the scope of competence of the EPPO should be enlarged to cover not only offences against the financial interests of the EU, but also other forms of serious cross border criminality. See: Conseil d'Etat, Rèflections sur l'institution d'un parquet europèen, 24 February 2011, p. 58.
} 
islative procedure, may establish a European Public Prosecutor's Office from Eurojust.

4. The European Council may, at the same time or subsequently, adopt a decision amending paragraph 1 in order to extend the powers of the European Public Prosecutor's Office to include serious crime having a cross-border dimension and amending accordingly paragraph 2 as regards the perpetrators of, and accomplices in, serious crimes affecting more than one Member State."

Article 86 TFEU further indicates that the regulation by which the EPPO will be established shall determine the general rules applicable to the EPPO, apart from the specific rules on criminal procedure that are mentioned:

Article 86:

"3. The regulations referred to in paragraph 1 shall determine the general rules applicable to the European Public Prosecutor's Office, the conditions governing the performance of its functions, the rules of procedure applicable to its activities, as well as those governing the admissibility of evidence, and the rules applicable to the judicial review of procedural measures taken by it in the performance of its functions (...)"

It is rather unclear if the phrasing "determine the general rules applicable" refers also to the applicable substantive criminal law or is limited to general principles sensu strictu.

The drafting of Article III-274 of the draft Constitutional Treaty and of Article 86 TFEU has predecessors, however and it is interesting to compare these text with the one of the draft of Article III- 175, prepared by the Convention ${ }^{4}$ :

Article III-175

" 1 . In order to combat serious crime having a cross-border dimension, as well as crimes affecting the interests of the Union, a European law of the Council of Ministers may establish a European Public Prosecutor's Office from Eurojust. The Council of Ministers shall act unanimously after obtaining the consent of the European Parliament.

2. The European Public Prosecutor's Office shall be responsible for investigating, prosecuting and bringing to judgement, where appropriate in liaison with Europol, the perpetrators of and accomplices in serious crimes affecting more than one Member State and of offences against the Union's financial interests, as determined by the European law provided for in paragraph 1. It shall exercise the functions of prosecutor in the competent courts of the Member States in relation to such offences.

3. The European law referred to in paragraph 1 shall determine the general rules applicable to the European Public Prosecutor's Office, the conditions governing the performance of its functions, the rules of procedure applicable to its

${ }^{4} \mathrm{CONV} 850 / 03140$. 
activities, as well as those governing the admissibility of evidence, and the rules applicable to the judicial review of procedural measures taken by it in the performance of its functions."

It is not only surprising that the material scope of competence included PIF-crimes as well as serious crimes having a cross-border dimension, but also that Article III175 (2) clearly indicated that the determination of the substantive criminal law would be part of the regulatory package of the establishment of the EPPO. It is also clear from Article III-175(3) that the general rules are thus something other than substantive criminal law.

It is also interesting to compare the text with the first proposal of the European Commission for a Treaty amendment in order to provide for a legal basis to establish an EPPO, namely the 2000 contribution to the Intergovernmental Conference on institutional reforms (preparing the Treaty of Nice) on "The criminal protection of the Community's financial interests: a European Prosecutor": 5

Proposed Article 280a:

"3. The Council, acting in accordance with the procedure laid down by Article 251, shall lay down the general conditions governing the performance of the functions of the European Public Prosecutor and shall adopt, in particular:

(a) rules defining the facts constituting criminal offences relating to fraud and any other illegal activity prejudicial to the Community's financial interests and the penalties incurred for each of them;

(b) rules of procedure applicable to the activities of the European Public Prosecutor and rules governing the admissibility of evidence;

(c) rules applicable to the judicial review of procedural measures taken by the European Public Prosecutor in the exercise of his functions."

In the Communication, the European Commission clearly insists on the full package and the relationship between substantive criminal law and criminal procedure:

"In conclusion, the Commission proposes that the Conference supplement the current provisions concerning the protection of the Community's financial interests with a legal basis allowing:

- the appointment of an independent European Public Prosecutor exercising the prosecution function in the courts of the Member States in the field of the protection of the Community's financial interests and within the framework of specific rules adopted for this purpose; and

- the subsequent adoption through secondary legislation of:

\footnotetext{
${ }^{5}$ Communication from the Commission: The criminal protection of the Community's financial interests: a European Prosecutor, COM (2000) 608 final, http://eur-lex.europa.eu/LexUriServ/LexUriServ.do? uri=COM:2000:0608:FIN:EN:PDF; for analysis see also the EC Green Paper on criminal-law protection of the financial interests of the Community and the establishment of a European Prosecutor, COM (2001) 715 final, http://ec.europa.eu/anti_fraud/documents/fwk-green-paper-document/ green_paper_en.pdf.
} 
- the regulations applicable to his office,

- rules of substantive law concerning the protection of financial interests by the European Public Prosecutor (offences and penalties),

- rules governing criminal procedure and the admissibility of evidence,

- rules concerning judicial review of actions taken by the Public Prosecutor in the performance of his duties." 6

We can thus conclude that Article 86 TFEU is phrased in an ambiguous way when it comes to the legal basis for harmonising the material scope of competence of the EPPO. Its predecessors were much clearer and did include an explicit reference to substantive criminal law as forming part of the EPPO regulatory package. However we can not conclude that the legislator has deliberately excluded substantive harmonisation from the phrasing under Article 86.

Given this intermediate conclusion it is wise to verify if there are other legal bases in the TFEU that could serve for the purpose of specifying the material scope of competence of the EPPO. In any case, Article 86 TFEU is part of the provisions in title V TFEU on an Area of Freedom, Security and Justice. Within Title V TFEU, there are various legal bases providing for the harmonisation of substantive criminal law, and thus for the harmonisation of the actus reus, mens rea of the offences and for the harmonisation of the applicable criminal penalties. The most obvious legal basis for harmonising substantive criminal law is the one provided for under Article 83 TFEU. It contains twin-track possibilities, as Article 83(1) TFEU deals with eurooffences and Article 83(2) deals with criminal law enforcement of harmonised areas:

Article 83 TFEU:

"1. The European Parliament and the Council may, by means of directives adopted in accordance with the ordinary legislative procedure, establish minimum rules concerning the definition of criminal offences and sanctions in the areas of particularly serious crime with a cross-border dimension resulting from the nature or impact of such offences or from a special need to combat them on a common basis. These areas of crime are the following: terrorism, trafficking in human beings and sexual exploitation of women and children, illicit drug trafficking, illicit arms trafficking, money laundering, corruption, counterfeiting of means of payment, computer crime and organised crime.

On the basis of developments in crime, the Council may adopt a decision identifying other areas of crime that meet the criteria specified in this paragraph. It shall act unanimously after obtaining the consent of the European Parliament.

2. If the approximation of criminal laws and regulations of the Member States proves essential to ensure the effective implementation of a Union policy in an area which has been subject to harmonisation measures, directives may establish minimum rules with regard to the definition of criminal offences and sanctions in the area concerned. Such directives shall be adopted by the same ordinary or special legislative procedure as was followed for the adoption of the harmonisation measures in question, without prejudice to Article 76."

${ }^{6} \mathrm{COM}(2000) 608$ final, p. 8. 
Article 83 directives are classic directives adopted under the co-decision procedure to which the Community method applies. There are nonetheless some particularities under Article 83. Not only is there an emergency brake, ${ }^{7}$ but there are Member States which either do not participate (Denmark) or have the privilege of an opting-in position (the United Kingdom and Ireland). When it comes to the criminal law enforcement of hard-core European interests, such as the combat against human trafficking in the AFSJ or the criminal law enforcement of market abuse and insider trading in the financial markets, ${ }^{8}$ it is strange that some EU Member States do not participate or do not opt-in (as the United Kingdom did for the draft directive on market abuse). ${ }^{9}$

Finally, the question arises (as it did in the past ${ }^{10}$ ) if and to what extent it is possible to harmonise substantive criminal law on the basis of other articles in the Treaties, outside the framework of Title V TFEU on the AFSJ and thus decoupled from the requirement of 'judicial cooperation in criminal matters' (which is the title of Chapter 4 of Title 5 TFEU). In the area of the protection of financial interests there is a specific provision in the TFEU, namely Article 325 TFEU:

\section{Article 325:}

" 1 . The Union and the Member States shall counter fraud and any other illegal activities affecting the financial interests of the Union through measures to be taken in accordance with this Article, which shall act as a deterrent and be such as to afford effective protection in the Member States, and in all the Union's institutions, bodies, offices and agencies.

(...)

4. The European Parliament and the Council, acting in accordance with the ordinary legislative procedure, after consulting the Court of Auditors, shall adopt the necessary measures in the fields of the prevention of and fight against fraud affecting the financial interests of the Union with a view to affording effective and equivalent protection in the Member States and in all the Union's institutions, bodies, offices and agencies."

Article 325 TFEU replaced the former Article 280(4) of the European Community Treaty (as inserted by the Treaty of Amsterdam) which contained the sentence "these measures shall not concern the application of national criminal law or the national administration of justice." This wording was deleted by the Lisbon Treaty. Article 235

\footnotetext{
${ }^{7}$ Article 83(3) provides of the ordinary legislative procedure".

${ }^{8}$ Luchtman \& Vervaele [9].

${ }^{9}$ For a more in detail analysis of Article 83 TFEU, see Vervaele [13].

${ }^{10}$ Vervaele [12].
}

"Where a member of the Council considers that a draft directive as referred to in paragraph 1 or 2 would affect fundamental aspects of its criminal justice system, it may request that the draft directive be referred to the European Council. In that case, the ordinary legislative procedure shall be suspended. After discussion, and in case of a consensus, the European Council shall, within four months of this suspension, refer the draft back to the Council, which shall terminate the suspension 
TFEU is a comprehensive article on the PIF-protection and contains a legal basis for the taking of measures in order to assure an effective and deterrent protection. Given the similar wording (fight against fraud affecting the financial interest of the Union) to that of Article 86 TFEU, these measures are clearly not limited to prevention. Moreover the article aims at affording effective and equivalent protection both at national level and at EU level (§3). So there is a certain logic to regarding Article 235 TFEU as a specialis in relation to the generalis article, Article 83(1-2). This does moreover exclude a couple of institutional disadvantages of Article 83(1-2) as this does not provide for an emergency break and does not include special positions for Member States (as non-participation or opting-in clauses). Finally, both directives and regulations can be adopted under Article 325. The tricky issue is if Chapter 4 of Title 5 and Article 83(1-2) are the exclusive legal basis in the TFEU for criminal law harmonisation or if this Article can be complemented by specific legal bases, such as that in Article 325 TFEU. The Treaty gives us no guidance on this point and it will be, if the points arise, for the Court of Justice to decide.

\section{The EPPO-proposal of the European Commission}

In July 2013, the European Commission submitted its proposal for a Council regulation on the establishment of the European Public Prosecutor's Office. ${ }^{11}$ From the recitals and the text it is clear that the Commission is aiming at a limited material scope of competence, and thus only PIF-offences and is excluding serious crimes having a cross-border dimension (recital 21 and Articles 4, 12). As regards the content of the material scope, the Commission definitely opts for a referral under national law, which criminalises acts or omissions affecting the Union's financial interest and determines the applicable penalties by implementing the relevant Union legislation, in particular through the new 2013 draft Directive, which still under negotiation, on the fight against fraud on the Union's financial interests by means of criminal law ${ }^{12}$ (recital 24). Furthermore the proposal extends the competence to offences that technically are not considered as PIF-offences, but that, because of their constituent facts, are identical and inextricably linked with those of the PIF-offences (so-called ancillary competence for mixed cases).

\section{Substantive harmonisation of PIF-offences ${ }^{13}$}

Do we really know today which offences fall within the ambit of crimes "affecting" the financial interests of the Union? And will the EPPO know tomorrow what the content is of "nullum crimen, nulla poena sine lege praevia"? And will the citizen

\footnotetext{
${ }^{11} \operatorname{COM}(2013) 534$ final, http://eur-lex.europa.eu/LexUriServ/LexUriServ.do?uri=COM:2013:0534:FIN: EN:PDF

${ }^{12}$ See point 4.

${ }^{13}$ Asp [2]; Sicurella [11], p. 885; Ligeti [8], 73-84.
} 
(suspect, victim, etc.) know tomorrow for which offences the EPPO can search and seize and can prosecute and which penalties could be applied?

The actual harmonisation of PIF-offences goes back to a legislative package of 1995, ${ }^{14}$ containing a Convention and several Protocols, provided for under the Maastricht Treaty. ${ }^{15}$ The Convention does not contain a specific list of PIF-offences, but rather a catch-all definition of fraud. The mens rea is clear, although the intentional nature of an act or omission may also be inferred from objective, factual circumstances (Article 1(4)). The actus reus is not clearly defined and contains rather a descriptive list of situations:

Article 1:

"1. For the purposes of this Convention, fraud affecting the European Communities' financial interests shall consist of:

(a) in respect of expenditure, any intentional act or omission relating to:

- the use or presentation of false, incorrect or incomplete statements or documents, which has as its effect the misappropriation or wrongful retention of funds from the general budget of the European Communities or budgets managed by, or on behalf of, the European Communities,

- non-disclosure of information in violation of a specific obligation, with the same effect,

- the misapplication of such funds for purposes other than those for which they were originally granted;

(b) in respect of revenue, any intentional act or omission relating to:

- the use or presentation of false, incorrect or incomplete statements or documents, which has as its effect the illegal diminution of the resources of the general budget of the European Communities or budgets managed by, or on behalf of, the European Communities,

- non-disclosure of information in violation of a specific obligation, with the same effect,

- misapplication of a legally obtained benefit, with the same effect."

Concerning criminal penalties, the Convention provides in Article 2 as follows:

Article 2:

"1. Each Member State shall take the necessary measures to ensure that the conduct referred to in Article 1, and participating in, instigating, or attempting the conduct referred to in Article 1(1), are punishable by effective, proportionate and dissuasive criminal penalties, including, at least in cases of serious fraud, penalties involving deprivation of liberty which can give rise to extradition, it

\footnotetext{
${ }^{14}$ The package contained also a regulation on administrative PIF-irregularities, regulation 2988/95 on the protection of the EC's financial interests (OJ L 312, 23 December 1995) and the legal basis for the OLAFregulation 2185/96 concerning on-the-spot checks and inspections carried out by the Commission in order to protect the European Communities' financial interests against fraud and other irregularities, OJ L 292, 15 November 1996.

${ }^{15}$ Convention of 26 July 1995, OJ C 316, 27 November 1995; First Protocol of 27 September 1996, OJ C 313, 23 October 1996 and second Protocol of 19 June 1997, OJ C 221, 19 July 1997.
} 
being understood that serious fraud shall be considered to be fraud involving a minimum amount to be set in each Member State. This minimum amount may not be set at a sum exceeding ECU 50 000."

It is clear from the outset that this harmonisation neither lays down a common term of imprisonment, nor minimum terms or maximum terms.

The result is that this package has been implemented by the Member States in their national legislation in a very slowly and unconvinced way. The picture is a complete patchwork. Some Member States considered that their legislation did comply under common fraud provisions in their criminal codes; others provided for specific offences but only linked, for instance, to subsidy-fraud - many did not elaborate specific criminal provisions in the area of structural funds. The result is also that not only the level of imprisonment but also the type of other criminal penalties is fully dependent upon the national legislator and thus does not offer a common set of equivalent standards of penalties in the AFSJ. The Commission's reports on the implementation of the PIF Convention and Protocols show a real patchwork of gaps and pieces as regards implementation. ${ }^{16}$ Even the anti-fraud unit of the EU (OLAF) has great difficulty in finding its way through the patchwork of applicable PIF-law in the Member States:

"The fact is that, nearly six years after the PFI convention was drawn up, the harmonisation objective has not been achieved and the whole area of the protection of Community financial interests continues to suffer from a lack of minimum standards of criminal law protection that can actually be applied throughout the European Union." 17

In the 1990s, within the Corpus Juris project, ${ }^{18}$ academic experts elaborated a concrete set of PIF-offences. Their work inspired the Commission when proposing a directive in 2001 on the criminal law protection of the Communities financial interest, based upon Article 280(4) of the Amsterdam Treaty. ${ }^{19}$ The draft directive, aimed at replacing the 1995 Convention and Protocols contained more specific criminal law definitions of fraud, corruption and related money laundering. However in the field of criminal penalties this proposal did not prescribe minimum or maximum penalties or types of penalties either. This draft directive became bogged down in negotiations, both due to problems concerning both its content and its legal basis ${ }^{20}$ and was thus never adopted.

\footnotetext{
${ }^{16}$ COM (2004) 709 final and COM (2008) 77 final.

${ }^{17}$ Point 1.2 of Explanatory Memorandum to Proposal for a directive on the criminal law protection of the Community's financial interests, COM (2001) 272 final, http://eur-lex.europa.eu/LexUriServ/ LexUriServ.do?uri=COM:2001:0272:FIN:EN:PDF. See also the two Reports of the Commission on the Implementation of the Convention on the Protection of the European Communities' financial interests and its protocols, of 2004 (COM (2004) 709 final) and 2008 (COM (2008) 77 final).

${ }^{18}$ Delmas-Marty [5]; Delmas-Marty \& Vervaele [4].

${ }^{19}$ COM (2001) 272 final.

${ }^{20}$ Article 280 was the predecessor of Article 325 TFEU. By using Article 280 the Commission avoided the criminal law harmonisation in the third pillar.
} 
In 2011 the European Commission insisted in its communication "On the protection of the financial interest of the EU by criminal law and by administrative investigations-An integrated policy to safeguard taxpayers' money" ${ }^{21}$ on the importance of substantive law harmonisation in the field:

\section{"4.2. Strengthening substantive criminal law}

Criminal law is a cornerstone of EU action to prevent and fight damage to the EU budget.

Due to the remaining loopholes in, and deficient implementation of, the Convention on the protection of financial interests, an initiative on the protection of EU financial interests will be prepared, replacing its pending proposal on the criminal-law protection of financial interests. Any new measure must guarantee consistency and fairness in application of criminal sanctions relating to fraud, depending on the particular way the offence was committed. Definitions of additional core offences, including on embezzlement and abuse of power should be envisaged as a part of the measure, to the extent relevant for the protection of EU financial interests. The approximation of rules on jurisdiction and time limitation will also be further analysed in order to improve criminal investigation results. This proposal may include, to the extent relevant for the protection of EU financial interests, more systematic rules on aiding and abetting, instigation, attempt, as well as on intent and negligence. It may also set out clearer rules on the criminal liability of appointed and elected office holders, and of legal persons regarding the protection of financial interests."

In 2012, the European Commission submitted a new proposal for a directive on the fight against fraud on the Union's financial interests by means of criminal law under the Lisbon Treaty. ${ }^{22}$ The proposal not only sought to "Lisbonise" the existing acquis, but also included in Article 2-6 two additional offences not covered by previous third pillar instruments, namely fraud in public procurement or grant procedures and misappropriation of funds. ${ }^{23}$ The Commission did not include all the offences listed in the Corpus Juris project, neither did it include criminal liability for legal persons. The provisions on penalties in Articles 7-9 were more innovative. Article 7 required penalties to be "effective, proportionate and dissuasive", but Article 8 set out very innovative imprisonment thresholds. Fraud on the EU, public procurement fraud and misappropriation of funds were to be punishable by a minimum penalty of at least six months imprisonment and a maximum penalty of at least five years imprisonment in cases involving an advantage or damage of at least $€ 100,000$. For money laundering and corruption, the same imprisonment thresholds were to apply in cases involving

\footnotetext{
${ }^{21}$ COM (2011) 293 final.

${ }^{22}$ COM (2012) 363 final.

${ }^{23}$ The Commission has reflected on including the other offences mentioned in the Corpus Juris, namely a specific offence of abuse of office and the breach of professional secrecy. However, the Commission decided not to include a special offence on abuse of office as "it has been considered a superfluous addition to the offence of misappropriation. Similarly, an offence of breach of professional secrecy has not been included in the proposal as the conduct is already covered under the disciplinary-law measures of the EU Staff Regulations." See Kuhl [7], p. 65.
} 
and advantage or damage of at least $€ 30,000$. In cases of involvement within a criminal organisation for all PIF-offences the minimum maximum penalty was required to be at least ten years imprisonment. The introduction of mandatory minimum penalties was entirely new. The proposed directive was based on Article 325(4) TFEU.

During the negotiations at Council level, Member States obtained very substantial changes to this proposal. In the agreed general approach in the Council in June 2013 the legal base was changed from Article 325(4) TFEU to Article 83(2) TFEU. From the opinion of the Legal Service of the Council, which were in favour of this change, it is clear that all the limitations (viz., the fact of not being applicable to Denmark, the opting in arrangement for the United Kingdom and Ireland, and the emergency brake procedure) apply. In the event of there being no opt-in by the United Kingdom and Ireland, these would remain bound by the 1995 PIF Convention. Secondly, the Member States have explicitly excluded revenues arising from VAT from the scope the directive. This is astonishing, as the Court of Justice has ruled clearly that VAT revenues are part of the financial interests of the Union, ${ }^{24}$ and many serious EU fraud cases are related to VAT carousel cases. In relation to penalties, Member States deleted from the text any reference to minimum terms of imprisonment. As regards the minimum maximum terms of imprisonment, this was lowered to at least four years in the case of serious offences.

Whether an offence is serious is defined according to national law, having regard to all relevant circumstances, such as the value of any damage done or advantages gained, or the damage to the integrity of or confidence in systems for managing the Union's financial interests (recital 16). The commission of an offence within a criminal organisation is an aggravating circumstance. At the time of writing (the end of January 2014) the proposal is being submitted to the co-decision procedure in the European Parliament. Both the Committee on Civil Liberties, Justice and Home Affaires (LIBE) and the Committee on Budgetary Control (COCOBU) of the European Parliament have amended substantially the Council text. They have reintroduced minimum sanctions and have widened the scope of offences to include fraud in public procurement and VAT fraud. By doing this, the text has been reoriented in the direction of the original Commission proposal.

\section{Conclusion}

The EPPO aims at establishing a coherent European system for the investigation and prosecution offences affecting the Union's financial interest. ${ }^{25}$ It also aims to contribute to a further development of an area of justice, and to enhance the trust of EU businesses and citizens in the Union's institutions, while respecting all fundamental rights enshrined in the Charter of Fundamental Rights of the European Union. ${ }^{26}$

Once the EPPO established, will a suspect know for which offences his can be held criminal liable and which penalties could be applied (substantive legality)? And

\footnotetext{
${ }^{24}$ Case C-539/09 Commission v Germany [2011] ECR I-11235, §72.

${ }^{25}$ Point 3.3 of the explanatory memorandum of the EPPO proposal.

${ }^{26}$ Idem.
} 
will the citizen (suspect, victim, etc.) know for which offences the EPPO can apply coercive measures, like searches and tapping of telecommunications, can prosecute and which penalties could be applied?

We have to take into account that the EPPO will bring suspects of PIF-offences to judgement before national courts, after having used a set of autonomous powers of investigation and prosecution. ${ }^{27}$ The choice of the forum court and thus the adjudicative jurisdiction is not predefined and Article 27 of the EPPO proposal contains only discretionary guidance as to the forum choice. This means that the suspect cannot foresee the forum in which he has to stand trial.

The European Commission has chosen to regulate the material scope of competence of the EPPO by harmonising national substantive criminal law through a directive based on Article 82(2). This means that equivalent components of substantive criminal law in the AFSJ for the competence ratione materiae of the EPPO depend on the level and content of the harmonisation in the directive and on the quality of the implementation in every single Member State.

As regards the level and content of the harmonisation by the directive, it follows from our analysis in this article that the Directive, like the PIF-Convention and the 1995 protocols, aims only at a very minimalistic degree of minimum harmonisation. The text which the Member States in the Council have agreed upon as a general approach and which is now under negotiation at the European Parliament has further watered down the minimum harmonisation which had been proposed by the Commission. The way the offences are spieled out in the draft directive leaves considerable leeway to the Member States when it comes to implementation. The fact that VAT has been deliberately excluded from the scope of application also means that the protection by criminal law of the financial interests of the Union does not apply to VAT fraud and to VAT fraud carousels. ${ }^{28}$ As regards the applicable criminal penalties, the general approach, agreed by the Council, does not at all result in foreseeable imprisonment terms, either as regards minimum levels or as regards precise maximum levels. Moreover the definition of the threshold of seriousness is left to national law. What does this mean as regards the level of implementation? Even when it comes to the common minimum harmonisation, Member States have a broad margin of discretionary power. Some of them will, as in the past, consider that their existing law does already provide for the criminal law protection and does not need any amendments, others will cherry pick, others will go beyond the minimum level of harmonisation required. The result is twofold. First, the existing fragmentation of the design of the PIF-offences in the legal orders of the Member States will not be ended; apart from there being a legislative patchwork, there will also be gaps in implementation. Secondly, the implementation of the directive will not lead to a clear and precise body of law of PIF-offences and penalties and the differences between the Member States will remain substantial. Even if the Parliament's plenary assembly agreed with the proposed amendments by the Civil Liberties, Justice and Home Affairs Committee and the Committee on Budgetary Control, not all the flaws stemming from the choice for a directive would be remedied.

\footnotetext{
${ }^{27}$ Recital 7 of the EPPO proposal.

${ }^{28}$ Ainsworth [1].
} 
This means that the suspect will have great difficulty knowing for which PIFoffences he can be held criminally liable and which penalties could be applied in all jurisdictions where he could stand trial. This means also that the substantive threshold for the triggering of autonomous European investigative measures will vary substantially from one Member State to another. Thus what results will be an unforeseeable "geométrie variable" instead of a clear, specific and definite body of offences and penalties. This lex uncerta and unpraevia is not only a substantial threat for the rights of suspects, but also a substantial source of legal problems for the use of coercive powers by the EPPO.

If we set up an EPPO, even with a structure that is strongly embedded in national law, a directive is definitely not the right instrument, as it aims at harmonising national law. What is needed is a harmonised body of offences and penalties, that are prescribed by a regulation and can be applied and by the EPPO in cross-border investigations and by the EPPO-Deputies in national settings. These offences must obviously correspond to the autonomous definition of PIF in EU law, as defined by the Court of Justice, and thus cover all fields, including, for instance, VAT and structural funds. This body of PIF-offences can be laid down at national level in a specific part of the Criminal Code or in a special criminal act or statute. This regulation can be part of one of the regulations based on Article 86 TFEU. ${ }^{29}$ Only by following this path will we arrive at a set of offences and penalties that will comply with the substantive legality principle and thus with the ECHR and Charter of Fundamental Rights of the European Union and that will serve as a common level playing field for the criminal law enforcement by the EPPO. Otherwise, the EPPO is condemned to act as a prisoner of a composite of national arrangements. The added value will be very doubtful and the risk of non-compliance with minimum ECHR and Charter of Fundamental Rights standards will be high.

\section{References}

1. Ainsworth, R.T.: Carousel Fraud in the EU; a digital VAT solution. Tax Notes Int. 42(5), 443448 (2006). Available at: http://128.197.26.34/law/faculty/scholarship/workingpapers/documents/ AinsworthR081006.pdf

2. Asp, P.: The Substantive Criminal Law Competence of the EU. Stockholms Universitet, Stockholm (2012)

3. Beccaria, C.: On Crimes and Punishment. Hackett Publishing, New York (1986)

4. Delmas-Marty, M., Vervaele, J.A.E.: Implementation of the Corpus Juris in the Member States, Vols. 1-4. Intersentia, Cambridge (2000-2002)

5. Delmas-Marty, M. (ed.): Corpus Juris portant dispositions pénales pour la protection des intérêts financiers de l'Union Européenne. Economica, Paris (1997)

6. Krey, V.: Keine Strafe ohne Gesetz: Einführung in die Dogmengeschichte des Satzes "Nullum Crimen, Nulla Poena sine Lege". De Gruyter, Berlin (1983)

7. Kuhl, L.: The initiative for a directive on the protection of the EU financial interests by substantive criminal law. Eucrim 2, 63-66 (2012)

8. Ligeti, K.: Approximation of substantive criminal law and the establishment of the European public prosecutor's office. In: Galli, F., Weyembergh, A. (eds.) Approximation of Substantive Criminal Law in the EU, pp. 73-84. Editions ULB, Bruxelles (2013)

${ }^{29}$ In the same vein of interpretation, see Picotti [10], see also on line: www.penalecontemporaneo.it. 
9. Luchtman, M.J.J.P., Vervaele, J.A.E.: Enforcing the market abuse regime (insider dealing and market manipulation): towards an integrated model of criminal and administrative law enforcement in the EU? (2014, forthcoming)

10. Picotti, L.: Le basi giuridiche per l'introduzione di norme penali comuni relative ai reati oggeto della competenza della Procura Europea. In: G. Grasso, G. Illuminati, R. Sicurella, S. Allegrezza (eds.) Le Sfide dell'Attuazione di Una Procura Europea: Definizione di Regole Comuni e Loro Impatto Sugli Ordinamenti Interni, pp. 65-108. Giuffré, Milano (2013, forthcoming)

11. Sicurella, R.: Setting up a European criminal policy for the protection of EU financial interests: guidelines for a coherent definition of the material scope of the European public prosecutor's office. In: Ligeti, K. (ed.) Toward a Prosecutor for the European Union, Vol. 1: A Comparative Analysis, pp. 870-904. Hart Publishing, Oxford (2013)

12. Vervaele, J.A.E.: The European Union and harmonisation of the criminal law enforcement of EU policies: in search of a criminal law policy. In: Cameron, I., Magnus, U. (eds.), European Union and Harmonization of Sanctions, Upsala (2014, forthcoming)

13. Vervaele, J.A.E.: Harmonised policies and the harmonization of substantive criminal law. In: Galli, F., Weyembergh, A. (eds.) Approximation of Substantive Criminal Law in the EU, pp. 43-72. Editions ULB, Bruxelles (2013) 